\title{
„ZWIĄZAĆ MOCARZA": STARCIE JEZUSA I BELZEBUBA. Starożytna egzegeza Mt 12, 29 oraz tekstów paralelnych ${ }^{1}$
}

\author{
„Jezu, Prawico Ojca, który zniszczyłeś Złego, \\ zepchnąłeś go aż do ostatecznej niskości \\ i zgromadziłeś jego dobra w miejscu \\ błogosławionego zgromadzenia!'’2
}

W Dziejach Apostolskich Piotr przypomina Korneliuszowi i jego bliskim, że przez swe życie publiczne w Galilei ,Jezus przeszedł dobrze czyniąc” (Dz $10,38)$, a sam Jezus, według Jana, powiedział: ,wiele dobrych uczynków pokazałem wam, od Ojca" (J 10, 32). Tymczasem, według trzech ewangelistów synoptycznych, był On oskarżany o „,wypędzanie złych duchów przez Belzebuba, księcia złych duchów" (Mt 12, 24; Mk 3, 22; Łk 11, 15). Z wielką cierpliwością Jezus podejmuje wówczas trud odparcia tego oskarżenia, odwołując się do prawdopodobieństwa (,czy szatan mógłby wypędzić szatana?”), a według Mateusza i Łukasza dodając argument ad hominem i a fortiori: ,jeśli ja przez Belzebuba wyrzucam złe duchy, to przez kogo je wyrzucają wasi synowie?" (Mt 12, 27 = Łk 11, 19). Pod koniec pierwszej części tej długiej apologii swojego działania, ciągnącej się w Ewangelii według św. Mateusza przez polemikę o ,znakach” i „wypędzaniu złych duchów” aż do 12, 45, Jezus proponuje, według wyrażenia Marka (Mk 3, 23), „przypowieść”, którą ze względu na zwięzłość, można by raczej nazwać ,apologiem”. To opowiadanie, obecne u trzech synoptyków, w tamtych czasach funkcjonowało też niezależnie, i było dość popularne, jak o tym świadczy np. Ewangelia Tomasza:

„Jest niemożliwe, aby ktoś wszedł do domu Mocarza i zawładnął nim przemocą, jeśli wpierw nie zwiąże mu rąk; dopiero wtedy będzie mógł zabrać ze sobą [zawartość] jego domu”’3.

${ }^{*}$ Prof. dr hab. Agnieszka Bastit-Kalinowska - maître de conférence Université de Lorraine (Metz), członek Institut Universitaire de France; e-mail: agnes.bastit@univ.lorraine.fr.

${ }^{1}$ Dziękuję Pani B. Rojek za pomoc przy redakcji polskiej wersji tekstu niniejszego artykułu.

${ }^{2}$ Acta Thomae 48, 1. Wszystkie przekłady z pism patrystycznych pochodzą od Autorki artykułu.

${ }^{3}$ Evangelium Thomae 35, thum. C. Gianotto (lekko zmodyfikowane): Évangile selon Thomas, w: Écrits apocryphes chrétiens, I, ed. P. Geoltrain - F. Bovon, Paris 1997, 40. 
Jednak wersją najbardziej rozpowszechnioną w starożytności chrześcijańskiej była wersja Mateuszowa, od której Marek różni się niewiele:

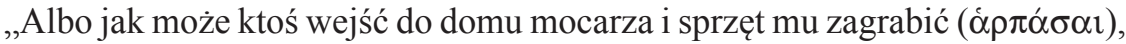
jeśli mocarza wpierw nie zwiąże? I dopiero wtedy dom jego ograbi

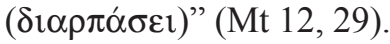

Poniższa tabela synoptyczna ukazuje różnice pomiędzy poszczególnymi wersjami:

\begin{tabular}{|c|c|c|c|}
\hline Evang. Thomae 35 & Mk 3, 27 & Mt 12, 29 & Lk 11, 21-22 \\
\hline $\begin{array}{l}\text { Jest niemożliwe, żeby } \\
\text { ktoś wszedł do domu } \\
\text { Mocarza i zawładnął } \\
\text { nim przemocą, jeśli } \\
\text { wpierw nie zwiąże mu } \\
\text { rąk; }\end{array}$ & 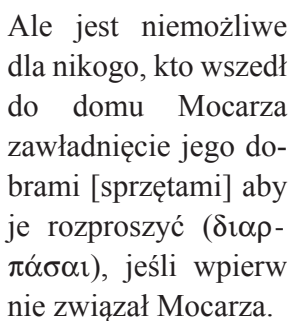 & $\begin{array}{l}\text { I jak ktoś mógł- } \\
\text { by wejść do domu } \\
\text { Mocarza i zagrabić } \\
(\alpha \rho \pi \alpha ́ \sigma \alpha \iota) \text { jego dobra } \\
\text { [sprzęty], jeśli wpierw } \\
\text { nie związał Mocarza? }\end{array}$ & $\begin{array}{l}\text { Bo kiedy Mocarz } \\
\text { uzbrojony strzeże } \\
\text { swego dworu, wtedy } \\
\text { to, co do niego należy } \\
\text { jest bezpieczne, }\end{array}$ \\
\hline $\begin{array}{l}\text { Wtedy dopiero bę- } \\
\text { dzie mógł zabrać ze } \\
\text { sobą [zawartość] jego } \\
\text { domu. }\end{array}$ & $\begin{array}{l}\text { Wtedy zagrabi jego } \\
\text { dobra (i je rozproszy: } \\
\delta \iota \alpha \rho \alpha \alpha \sigma \varepsilon \imath)\end{array}$ & $\begin{array}{l}\text { Wtedy zagrabi jego } \\
\text { dobra (i je rozproszy: } \\
\delta ı \rho \pi \alpha ́ \sigma \varepsilon \imath)\end{array}$ & $\begin{array}{l}\text { ale gdy nadejdzie } \\
\text { mocniejszy od niego } \\
\text { i pokona go, zabierze } \\
\text { całą jego broń, na któ- } \\
\text { rej [Mocarz] polegał, } \\
\text { a łupy jego rozda. }\end{array}$ \\
\hline
\end{tabular}

Oryginalność wersji Łukasza rzuca się w oczy, w przeciwieństwie do zgodności wersji Mateusza, Marka i Ewangelii Tomasza, które różnią się nieznacznymi szczegółami. Tej najpowszechniejszej wersji i jej odbiorowi w Kościele pierwotnym poświęcona jest niniejsza nota, mimo że wersja Łukasza, choć reprezentowana przez mniejszość starożytnych autorów, nie może być całkiem ignorowana. Apolog „mocarza pokonanego”, który u synoptyków następuje bezpośrednio po argumentacji Jezusa broniącego się przed zarzutem wyrzucania złych duchów ,przez Belzebuba”4, otrzymuje w tym kontekście, jak na to wskazują Ireneusz, Tertulian lub Chromacjusz z Akwilei ${ }^{5}$, domyślne zastosowanie, które może być sformułowane następująco: Jezus jest dla Belzebuba

${ }^{4}$ Por. F. Bovon, L'évangile selon saint $\operatorname{Luc}$ (9, 51 - 14, 35), Genève 1996, który komentuje wersję Łukasza na stronach 151-168, wzmiankuje o etymologii tej bardzo rzadkiej nazwy - „pan wzniesionego domu” („maitre de la demeure élevée”), ukazując powiązanie między tą nazwą i opowiadaniem o ,siedzibie czy domu mocarza” (s. 158-159).

${ }^{5}$ Por. Irenaeus, Adversus haereses III 8, 2, ed. F. Sagnard, SCh 34, Paris 1952, 146: „Gdy ogłosił diabła mocarzem, nie w zupełności ale w stosunku do nas, «On sam Pan okazał się prawdziwie mocnym»"; Tertullianus, Adversus Marcionem IV 26, 12, ed. C. Moreschini - R. Braun, SCh 456, Paris 2001, 342: „Słusznie więc zastosował przypowieść o tym słynnym «mocarzu» uzbrojonym, którego mocniejszy zmiażdżył, do «księcia demonów», którego nazwał wyżej «Belzebubem» $\mathrm{i}$ «Szatanem»; Chromatius Aquileiensis, Tractatus in Matthaeum 50, 1, ed. R. Étaix - J. Lemarié, 
tym, kim zwycięzca jest dla „mocarza”, natomiast jego „dobra” lub „sprzęty” przedstawiają ludzi poddanych różnym demonom, czyli trzymanych przez demoniczną moc, jak to pokazuje następująca tabela:

\begin{tabular}{|c|c|}
\hline Apolog & Sugerowane zastosowanie \\
\hline Mocarz & Belzebub (lub Szatan) \\
\hline Mocniejszy & Jezus Chrystus \\
\hline Dobra mocarza & Ludzie poddani mocom demonicznym \\
\hline
\end{tabular}

Od tego ukrytego zastosowania, zasugerowanego w ewangeliach kanonicznych, będzie zależała cała interpretacja poświadczona w starożytnym Kościele. Nie zdziwimy się więc widząc, że ten werset nabiera znaczenia podsumowania kerygmatycznego, którego treść dla pierwotnego Kościoła odpowiada temu, co - według Orygenesa - sam Pan „mówił w sposób ukryty”: Chrystus wyzwolił ludzi spod tyrańskiego wpływu szatana i - szerzej - od zła i śmierci. Komentatorzy zidentyfikują tylko w uzupełnieniu „dom mocarza” i zainteresują się różnymi czasami ekonomii zbawienia reprezentowanymi przez różne momenty akcji opowiedzianej w apologu. Powołując się na praktykę mojego mistrza Antonio Orbe, zwolnię się częściowo z ukazywania ścisłej sukcesji historycznej, aby przedstawić dwie główne linie interpretacyjne tego wersetu, jedną potwierdzoną już u Melitona z Sardes, a zilustrowaną szczególnie przez Orygenesa, drugą reprezentowaną przez Ireneusza i jego spadkobierców.

1. Linia angelologiczna: zbiór Pawłowy lub walka z mocami. Najstarsze użycie tego wersetu u Melitona z Sardes, w hymnie końcowym Homilii paschalnej, umieszcza apolog synoptyczny w bogatym arsenale motywów Pawłowych:

„[Chrystus] powstawszy z martwych zakrzyknął wielkim głosem: «Kto się odważy ze Mną spór toczyć?» (Iz 50,8) [...] Kto przeciw mnie wystąpi? To ja, mówi On, jestem Chrystusem, to ja śmierć zniszczyłem (por. 1Kor 15,26 ), odniosłem tryumf nad wrogiem (por. Kol 2, 15), zdeptałem piekło, «związałem mocarza i zawładnąłem» (’̉ $\varphi \alpha \rho \pi \alpha ́ \sigma \alpha \varsigma, ~ M t ~ 12,29)$ człowiekiem, aby wynieść go na wyżyny niebios (por. Ef $4,8 \mathrm{nn}$.). Ja jestem, powiedział, Chrystus"?.

CCL 9A, Turnhout 1974, 445: „On tu pokazał że «mocarzem» był Szatan, książę złych duchów [...]. Dowiadujemy się więc, że «mocarzem» był diabeł, dzięki tym samym słowom Pana”.

${ }^{6}$ Origenes, Commentarii in Epistulam ad Romanos V 10, ed. C.P. Hammond Bammel M. Fédou - L. Brésard, SCh 539, Paris 2010, 516.

${ }^{7}$ Melito Sardensis, De Pascha 101-103, ed. O. Perler, SCh 123, Paris 1966, 120-122. Pytanie zapożyczone z Księgi Izajasza: „Kto się odważy ze Mną spór toczyć?” (Iz 50, 8) pokazuje, że Meliton był uczulony na kontekst kontrowersji dotyczącej zdania o mocarzu w ewangeliach synoptycznych. 
Trzeba zaznaczyć, że deklaracja ,ja związałem mocarza” włożona w usta Zbawiciela po Jego zmartwychwstaniu, a nawet $p o$ wniebowstąpieniu, jest dla Melitona znakiem, że w apologu Mt 12, 29 i wersjach paralelnych Jezus określił własną działalność: Zbawiciel bierze w posiadanie to, co było zatrzymane przez innego. W związku z tekstami Pawłowymi, które rozwijają temat walki Chrystusa ze śmiercią, z Nieprzyjacielem i z mocą piekieł, wejście do domu „mocarza” jest usytuowane w momencie zstąpienia Zbawiciela do piekieł. Szczytem i zakończeniem tego jest powrót człowieka do jego prawowitego Pana, a ostatecznie jego wyniesienie na niebiosa. W tym sensie końcowa aluzja do trochę enigmatycznego wersetu Ef 4, 8 (por. Ps 68, 19) - „wstąpiwszy do góry wziął do niewoli jeńców" wydaje się być ponownym zapisem akcji $\mathrm{z}$ apologu: to wyzwolenie dokonuje się $\mathrm{w}$ ramach ponownego wejścia $\mathrm{w}$ górę. Stosując imiesłów ỏ $\varphi \alpha \rho \pi \alpha ́ \sigma \alpha \varsigma$, Meliton przejmuje od Mateusza czasownik

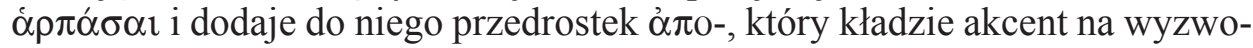
lenie człowieka, oswobodzonego z tego, co go trzymało.

Orygenes jest uprzywilejowanym świadkiem tego sposobu odczytywania analizowanego tekstu. Upłynął jakiś czas od 2. poł. II w., gdy Meliton komponował swój hymn paschalny, mimo to Orygenes w swoim komentarzu do Listu do Rzymian, przetłumaczonym i zaadaptowanym przez Rufina ${ }^{8}$, oddaje bardzo wiernie echo zbioru pism Pawłowych, obecne już u Azjaty i wzbogaca go dodatkowo zbliżonymi tonami harmonicznymi. W komentarzu do Listu do Rzymian 6, 9 (,śmierć nad nim nie ma już władzy”), Orygenes dystansuje się od tych, którzy to stwierdzenie rozumieją dosłownie jako oznaczające, że człowieczeństwo Jezusa zmartwychwstałego nie zazna już więcej śmierci biologicznej. Przez ,śmierć” wspomnianą tu przez Pawła woli on rozumieć „ostatecznego Nieprzyjaciela”, unicestwionego w 1Kor 15, 26. Odnosząc się do modelu Jonasza, o którym sam Jezus powiedział, że jak on pozostanie „trzy dni i trzy noce w łonie ziemi” (Mt 12, 40), komentator rozwija „podobieństwo", aby wyraźnie sprecyzować celowość wcielenia: Zbawiciel miał przyjść do ludzi, ukrywając swoją prawdziwą naturę i pochodzenie, działając - można powiedzieć - za pomocą specjalnych sił, aby mógł być jak najbliżej potęgi nieprzyjaciela, z założenia tyrańskiej. Mając możność dojścia do samego środka nielegalnej władzy, we właściwym momencie (tempore opportuno) neutralizuje siły nieprzyjaciela:

\footnotetext{
${ }^{8} \mathrm{~W}$ swoich Homiliach o Księdze Jozuego, także thumaczonych przez Rufina, à propos triumfalnego dźwięku trąb w Jerychu, Orygenes operuje tym samym porównaniem między triumfem nad mocami, proklamowanym przez List do Kolosan 2, 15 i apologiem z Mt 12, 29. Perspektywa jest kosmiczna i przywołuje opozycję dwóch obozów niebieskich, z których jeden triumfuje, widząc „księcia tego świata” sprowadzonego do niemocy przez czyn Zbawiciela: „Słuchaj [Pawła] mówiącego: «on ogołocił księstwa [...] wystawił je w triumfie na drzewie «krzyża». Na podstawie tych słów rozumiem, że widząc walkę Jezusa i wrogich mocy pozbawionych swej władzy, widząc "związanego mocarza i jego wyrwane sprzęty», moce niebiańskie zagrały na niebiańskich trąbach, bo po związaniu księcia tego świata świat jest zwyciężony [...]”, por. Origenes, In Iesu Nave hom. 7 , 3, ed. A. Jaubert, SCh 71, Paris 1960, 202-204.
} 
„On wziął z zewnątrz tych, którzy byli podporządkowani tyranowi, aby móc [...] w stosownym momencie, «związać samego mocarza» (Mt 12, 29), «rozbroić zwierzchności i władze» (Kol 2, 15), «w końcu pociągnąć za sobą jeńców» wyrwanych temu, który ich więził (por. Ef 4, 8). Podobnie «Chrystus dobrowolnie ogołocił samego siebie, przyjął postać sługi i poddał się dominacji tyrana, stawszy się posłusznym aż do śmierci» (Flp 2, 7); a przez tę śmierć «pokonał tego, który dzierżył władzę nad śmiercią, to jest diabła» (Hbr 2, 14), aby wyzwolić tych, którzy byli więzieni przez śmierć"’.

Zbiór odnośników Pawłowych, obecny już u Melitona, wzbogacił się tutaj o cytat z Listu do Hebrajczyków 2, 14, który wprowadza przypomnienie o zstąpieniu duszy Jezusa do piekieł, bo Orygenes w „narzędziach” wyrwanych przez Zbawiciela widzi ,dusze”, które dostały się pod władzę śmierci:

„Istotnie, On «związał mocarza», ponieważ zatriumfował nad nim na krzyżu (por. Kol 2, 15), wszedł również do jego posiadłości, do «domu mocarza», do piekła, i zawładnął jego sprzętami, to znaczy, że pociągnął za sobą dusze, które on [diabeł] więził. To łączy się z tym, co sam Pan mówił w sposób ukryty w ewangelii (Mt 12, 29). Związał On go więc «wpierw» (prius) na krzyżu (por. Kol 2, 14 i zapis dłużny przybił do krzyża) i odtąd «wstąpiwszy do góry, wziął do niewoli jeńców» (Ef 4, 8), tych niewątpliwie, którzy z nim zmartwychwstali i weszli [z nim] do miasta świętego, Jeruzalem niebiańskiego (por. Mt 27, 52-53)"10.

Ten tekst obrazuje ten sam podwójny ruch opadania, a potem wznoszenia, co hymn końcowy Melitona ${ }^{11}$. Zauważmy jak Orygenes podkreśla znaczenie słowa „,wpierw” ( $\pi \rho \hat{\omega} \tau$ ○v, prius) w mikro-opowiadaniach Mateusza i Marka.

2. Perspektywa ekonomiczna: Odkupiciel człowieka. Również Ireneuszowi zdarza się łączyć sentencję z Ewangelii Mateusza z Pawłową wizją walki przeciw „ostatecznemu nieprzyjacielowi”, ale myśli, które zajmują jego umysł, są zorientowane w innym kierunku i nie ograniczają się do rozwijania kwestii walki:

„Ponieważ Bóg nie może być zwyciężony [...] przez drugiego człowieka, «związał on mocarza i zawładnął jego sprzętami» (Mt 12, 29), «pokonał

\footnotetext{
${ }^{9}$ Origenes, Commentarii in Epistulam ad Romanos V 10, SCh 539, 514.

${ }^{10}$ Tamże V 10, SCh 539, 516.

${ }^{11} \mathrm{~W}$ duchu tonacji tak samo „heroicznej” Hieronim (Commentarius in Matthaeum 12, 29, ed. É. Bonnard, SCh 242, Paris 1977, 248) pamięta o starej historii o Tyfonie, opowiedzianej przez Hezjoda, przedstawiając mocarza wrzuconego i zamkniętego „na dnie piekła”. Być może w tym samym sensie należy odczytywać aluzyjny pasaż hymnu chrystologicznego z Dziejów Tomasza 48, 1: „Jezu, Prawico Ojca, który zniszczyłeś Złego, zepchnąłeś go aż do ostatecznej niskości i zgromadziłeś jego dobra w miejscu błogosławionego zgromadzenia!”. „Mocarz” jest tu bardziej wprost nazwany „Złym”, a ostateczna niskość odpowiada głębi piekieł, skąd „dobra” lub „sprzęty” mocarza zostały szczęśliwie wydobyte przez Zbawiciela, który przeniósł je w miejsce błogosławieństwa.
} 
śmierć» (1Kor 15, 26), ożywiając człowieka, którego ta śmierć dosięgła. Pierwszym naczyniem wciągniętym w jego posiadanie był w istocie Adam, którego trzymał on w swojej mocy"12.

Perspektywa Ireneusza jest tu dość bliska temu, co będzie perspektywą Orygenesa: Mocarz jest porównany do „,ostatecznego Nieprzyjaciela”, nad którym Zbawiciel musi mieć przewagę, a wspomnienie o Adamie pozwala myśleć o pobycie protoplasty w Hadesie ${ }^{13}$. Jednak właściwy Ireneuszowi styl ukazuje się, gdy w ślad za Ef 4, 8 tłumaczy on lub dopełnia pokonanie śmierci przez udzielony człowiekowi dar „ożywienia”, potem niezniszczalności.

Według Ireneusza, którego interpretacja zapisała się w tradycji Kościoła,

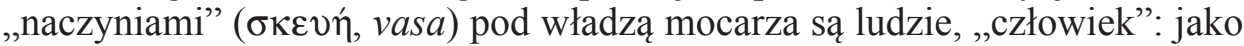
pierwszy (wbrew Tacjanowi) „Adam”, „człowiek” sam w sobie ${ }^{14}$, „ludzie, którzy byli przez niego (mocarza) więzieni" ${ }^{15}$, „ludzie, którzy przeszli na jego służbę"16; „otóż tymi naczyniami i tym domem byliśmy my, będąc jeszcze w stanie apostazji"17.

Ireneusz wyjaśnia sentencję z Mt 12, 29 w kilku strategicznych miejscach Adversus haereses, w księgach: III, IV i V, w których - w odpowiedzi na różne teologie i egzegezy gnostyckie - opracowuje, opartą na lekturze Pism, swoją własną teologię, którą przedstawia jako tradycyjną, ale która jednak często świadczy o jego osobistym rozważaniu komentowanego tekstu biblijnego. Ponadto, rzeczywiście, w tych ośmiu przypadkach komentuje niemal wszystkie elementy wersetu: Na czym polega siła „mocarza”?; Jakiej natury jest opozycja między ,mocarzem” a ,mocniejszym”?; stosunek „,mocarza” do swoich „,óbr” lub „naczyń”; przestawienie czasów, szczególnie między akcją daną jako „uprzednią” i akcją daną jako „późniejszą”, ale także określenie czasu, w którym miała miejsce wyjściowa relacja o mocy; wreszcie sposób odniesienia zwycięstwa i sposób „zdobycia” dóbr strzeżonych przez mocarza. Zwróćmy uwagę, że jeśli „,dom” jest brany w znaczeniu „domowników”

${ }^{12}$ Irenaeus, Adversus haereses III 23, 1, ed. A. Rousseau - L. Doutreleau, SCh 34, Paris 1952, 382.

${ }^{13}$ Dla Ireneusza ,aktywność Chrystusa w piekle jest streszczona w logion Pseudo-Jeremiasza, cytowanym przez Ireneusza sześć razy: „«Pan, Święty Izraela wspomniał na swoich zmarłych śpiących w ziemi grobu; zszedł On ku nim, aby im ogłosić zbawienie i uratować ich» [...] Zszedł On do Hadesu, aby przez Ewangelię wzbudzić u wierzących śpiących, wiarę i nadzieję w Nim [...], niezbędną dla ich zbawienia", por. A. Orbe, Introduccion a la teologia de los siglos II y III, II, Roma 1987, 849. Aluzje Ireneusza pozostają rzeczywiście dyskretne; nie wydaje się, aby zejście do piekieł było przez niego widziane inaczej, niż jako „ewangelizacja” swych ojców przez Chrystusa, przy czym miejscem decydującego starcia jest w oczach Ireneusza męka i śmierć na krzyżu, a nie zstąpienie do piekła.

${ }^{14}$ Por. Irenaeus, Adversus haereses IV 33, 4, ed. A. Rousseau - B. Hemmerdinger - L. Doutreleau - Ch. Mercier, SCh 100/2, Paris 1965, 810-812; tamże V 21, 3, ed. A. Rousseau - L. Doutreleau - Ch. Mercier, SCh 153, Paris 1969, 274-278.

${ }_{15}$ Tamże V 21, 3, SCh 153, 276.

${ }^{16}$ Tamże III 8, 2, SCh 34, 146.

${ }^{17}$ Tamże. 


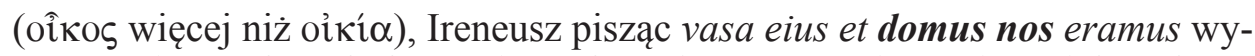
strzega się w tekstach, które się zachowały, oznaczenia „świata” jako „domu mocarza" - a nawet wyraźnie oskarża on szatana o kłamstwo, gdy tamten twierdzi, że królestwa ziemi są pod jego władzą.

Ogólnie można powiedzieć, że jego podejście jest mniej kosmiczne, niż Orygenesa: jest przede wszystkim czasowe, doczesne i ekonomiczne, biorące pod uwagę dzieje zbawienia: interesuje się on wprowadzanymi tu czasami i realiami, które się dzieją:
„Ale gdy nazwał diabła «mocarzem», to nie w sensie absolutnym, lecz w po- równaniu do nas, gdyż to sam Pan okazał się być we wszystkim prawdziwym «Mocarzem» (por. Mt 12, 29). Otóż to my sami byliśmy jego naczyniami i jego domem, gdy byliśmy w apostazji: «duch nieczysty» (Mt 12, 43) mieszkał w nas i posługiwał się nami do woli ${ }^{18}$. To nie względem Tego, kto go związał i za- władnął jego domownikami, był on mocny, lecz w stosunku do ludzi, którzy byli na jego usługach, bo on był powodem odwrócenia się od Boga woli tych, których Pan [następnie] wyrwał. Jak to powiedział Jeremiasz: «Pan odkupił Jakuba i wyrwał go z ręki silniejszego niż on» (Jr 31, 11 [Jr 38, 11, LXX])”'19.

W tym paragrafie księgi III Adversus haereses, gdzie werset Mt 12, 29 pojawia się po raz pierwszy, Ireneusz precyzuje kiedy „,człowiek” (on pisze „my”) przeszedł pod panowanie „mocarza”: w momencie, w którym [szatan] „spowodował odwrócenie się od Boga woli ( $\gamma \nu \omega ́ \mu \eta$, sententia) tych, których Pan [następnie] wyrwał" z tej niewoli. Można więc wyróżnić trzy czasy:

1. moment początkowy przejścia do apostazji, odpowiadający opowiadaniu o kuszeniu pierwszego człowieka w Księdze Rodzaju, wyrażony przez Ireneusza w czasie zaprzeszłym plusquamperfectum (abscedere fecerat sententiam eorum a Deo): ludzie zostali wtedy związani przez bezsilność i zranieni przez grzech i śmierć;

2. czas apostazji, od grzechu pierworodnego aż do przyjścia Syna Bożego: ludzie byli tu związani i poddani władzy mocarza, w trybie oznajmującym czasu przeszłego niedokonanego (in usu eius erant homines);

3. moment odkupienia, w którym Jezus ,wyrwał” ich spod władzy tego, który nielegalnie nad nimi panował, wyrażony w trybie oznajmującym czasu przeszłego dokonanego: eripuit Dominus ${ }^{20}$.

Należy zauważyć, że Ireneusz wyraźnie zapożycza to eripuit (diripuit w manuskryptach A i V) od Jeremiasza według Septuaginty. Całość paragrafu koń-

${ }^{18}$ Wbrew transformacji przedstawionej przez manuskrypt C, który zamiast ,spiritus immundus habitabat in nobis” (Mt 12, 43) odczytał ,in mundo habitabat in nobis” (por. SCh 34, 146 - aparat krytyczny).

${ }^{19}$ Irenaeus, Adversus haereses III 8, 2, SCh 34, 146.

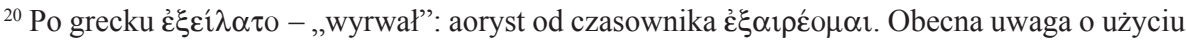
czasów w passusach Ireneusza, które podejmują Mt 12, 29, jest ogólna i stosuje się również do innych cytatów zamieszczonych niżej. 
czy się tym cytatem z Jeremiasza: „Redemit Dominus Iacob et eripuit eum de manu fortioris eius" (Pan odkupił Jakuba i wyrwał go z ręki silniejszego niż on, Jr 38, 11, LXX).

Poza tą retrospekcją ekonomiczną, myśl Ireneusza staje się autentycznie teologiczna, gdy stara się on odkryć to, co uzasadnia dysproporcję strukturalną, więcej, istotową i ontologiczną, sił relatywnych „mocarza”: „mocniejszego" niż człowiek, według słów Jeremiasza, a jeszcze „mocniejszego”, którym jest Zbawiciel. Już w pierwszych słowach, które poświęcił wersetowi, zapisał, że ten „mocarz" nie jest nim w sposób absolutny, ale w porównaniu z nami. Więc, aby okazać się „mocniejszym” (według Łukasza), trzeba mieć „coś więcej” niż człowiek od początku zraniony. Komentując w ramach tej samej polemiki na temat autorytetu Jezusa Jego deklarację, według której „tu jest coś więcej niż Salomon, więcej niż Jonasz" (Mt 12, 41-42), Ireneusz dodaje:

„W jaki sposób miał on więcej niż Salomon lub niż Jonasz i był Panem Dawida, On który był z nimi wspólistniejący (eiusdem cum ipsis substantiae)? I w jaki sposób mógł pokonać tego, który był mocarzem wobec człowieka, który nie tylko pokonał był człowieka, ale go trzymał pod swoją władzą? I w jaki sposób zwyciężył tego, który był zwyciężył, i odesłał wolnym człowieka, który był [wcześniej] zwyciężony, jeśli nie byłby «mocniejszy» od człowieka, który był [wcześniej] pokonany? Kto inny mógłby [być] lepszym i doskonalszym od człowieka uczynionego na podobieństwo Boga, niż Syn Boży, na podobieństwo którego człowiek został stworzony?’"21

Refleksja Ireneusza sięga do początku człowieka, do samego celu jego kształtowania - człowiek został stworzony „na podobieństwo” Słowa i Syna Bożego: „siła”, którą ten ostatni manifestuje w swoim zwycięstwie nad ,mocarzem”, jawi się jako obiecana człowiekowi, który już ją potencjalnie otrzymuje w samej swojej konstytucji, która upodabnia go możliwie najlepiej do Syna Bożego jako najwyższego wzoru. Przyjście Słowa w fakcie wcielenia opiera się już na tej pierwotnej bliskości i podobieństwie, wpisanych w samą konstytucję człowieka.

Ireneusz interesuje się relacją Boga do człowieka, stosunkiem Stwórcy do jego Nieprzyjaciela, a także tego co wcześniejsze, do tego co późniejsze, i jest szczególnie czujny na podwójne relacje równorzędności lub odwetu. Znajduje upodobanie w wyrażaniu symetrii wzajemnych postaw (por. „niewola uwięziona” Ef 4, 8) - „on istotnie trzyma tego, który «wiąże», ale ten, który «jest związany», jest trzymany"22; lub w formułach odwracalnych, i lubi podkreślać odwracalność sytuacji potęgi i niemocy: według Ireneusza, Pan „,pokonał tego, który (wcześniej) pokonał (eum quidem qui vicerat vicit)”23, ,jego węzły

\footnotetext{
${ }^{21}$ Irenaeus, Adversus haereses IV 33, 4, SCh 100/2, 812.

${ }^{22}$ Tamże III 8, 2, SCh 34, 146-148.

${ }^{23}$ Tamże IV 33, 4, SCh 100/2, 812.
} 
[mocarza] były rozwiązaniem człowieka" ${ }^{24}$, ze względu na możliwą odwracalność więzów i węzłów 25 :

„Ponieważ na początku [mocarz] przekonał człowieka do przekroczenia przykazania danego mu przez Stwórcę, i więził go w swojej mocy, a ta moc nie jest niczym innym jak pogwałceniem prawa i odstępstwem, przez które związał on człowieka, więc było pożyteczne [wypadało], żeby, kolejno przez samego człowieka [mocarz] został zwyciężony, żeby odwrotnie, był związany tymi samymi więzami, którymi on związał człowieka, aby uwolniony człowiek mógł wrócić do swojego Pana"226.

Początkowy zwycięzca jest zwyciężony, ten który wiązał - związany, według wymogu sprawiedliwości: to człowiek był zwyciężony na początku, wypada więc, aby z kolei był jakiś człowiek, który uwolni człowieka z jego więzów. Symetria i odwracalność są sformułowaniami, które wyrażają identyczność natury człowieka zwyciężonego na początku i człowieka będącego ostatecznie zwycięzcą: ten człowiek to Jezus, współistniejący ze swymi braćmi w człowieczeństwie, który ma przewagę nad „mocarzem”. W perspektywie ekonomicznej Ireneusza, zwycięstwem prawdziwego „mocarza” był ten moment największej miłości do ludzkości, w którym stał się on „posłuszny aż do śmierci” (Flp 2, 8), ,przez posłuszeństwo rozwiązując nieposłuszeństwo”, i już wcześniej moment jego wierności słowu Ojca podczas pierwszego starcia z pokusami ${ }^{27}$. W skierowanej przeciw doketyzmowi medytacji nad rzeczywistością cierpień Jezusa podczas męki, Ireneusz pokazuje, jak daleko posuwa się miłosierdzie Boże:

„Ponieważ Syn Boży jest prawdziwie dobry i cierpliwy, Słowo Boga Ojca stało się Synem człowieczym. Rzeczywiście On walczył i zwyciężył. Był istotnie człowiekiem walczącym za swych ojców ${ }^{28}$, a przez swoje posłuszeństwo rozwiązującym węzły nieposłuszeństwa, bo związał mocarza i uwolnił chorych, obdarowując zbawieniem [w ciele] swoje stworzone dzieło i niszcząc grzech. Zdecydowanie prawdą jest, że Pan jest «bardzo życzliwy i miłosierny» (Ps 102, 8) oraz jest «przyjacielem rodzaju ludzkiego»" ${ }^{\prime 2}$.

\footnotetext{
${ }^{24}$ Tamże V 21, 3, SCh 153, 274-276.

${ }^{25}$ Por. odwracalność węzłów w Ewie i w Maryi. W księdze III Adversus haereses, w tym samym rozdziale, gdzie mówi się o inobaudientiae nodus, Ireneusz pisze, że „to co Ewa, dziewica, związała przez swój brak wiary, Maryja, dziewica, rozwiązała przez wiarę" (Adversus haereses III 22, 4, SCh 34, 382). Między nimi obiema jest recircumlatio, zob. A. Bastit, Le salut comme libération dans l'exégèse primitive des évangiles: LUO et LUSIS, w: Pagani e Cristiani alla ricerca della salvezza (secoli I-III). XXXIV Incontro di studiosi dell'antichità cristiana, Roma 2006, 293.

${ }^{26}$ Irenaeus, Adversus haereses V 21, 3, SCh 153, 274-276.

${ }^{27}$ Por. tamże.

${ }^{28}$ Głównie - według Ireneusza - za Adama i Ewę, jak ukazuje podobna przypowieść o uzurpatorze, wymyślona i opowiedziana w Adversus haereses III 23, 2, SCh 34, 384-386.

${ }^{29}$ Irenaeus, Adversus haereses III 18, 6, SCh 34, 324.
} 
W dalszym ciągu tego tekstu Ireneusz rozwija za pomocą zrównoważenia symetrycznego, które lubi, argumentację ${ }^{30}$ zmierzającą do ukazania, dlaczego trzeba było, żeby zwycięzca był zarazem autentycznym ,człowiekiem” i w pełni Bogiem:

„On więc zjednoczył ściśle człowieka z Bogiem. Bowiem, gdyby to nie człowiek był zwycięzcą przeciwnika człowieka, nieprzyjaciel nie byłby zwyciężony sprawiedliwie; i odwrotnie, gdyby Bóg nie udzielił daru zbawienia, z pewnością nie otrzymalibyśmy go"31.

Sam więc Jezus, współistniejący tak z człowiekiem, jak i z Ojcem, może walczyć naprawdę i mieć wieczną przewagę. W końcu Stwórca ukazuje się „niezwyciężony” w swojej suwerennej i absolutnej potędze, prawdziwie transcendentnej: gdyby nie była dodana żadna inna wzmianka, notuje Ireneusz, ten „mocarz” okazałby się niezwyciężony; natomiast gdy ma miejsce wzmianka o ostatecznym zwycięzcy, nie będzie już mowy o mocy względnej, ,aby niewolnik, odstępca nie mógł być porównywany ze swoim Panem"32. Więcej: zwycięstwo Stwórcy nie polega po prostu na przywróceniu jego praw nad nielegalnym uzurpatorem, lecz pozwala ono na pełny rozwój aż do niezniszczalności, na „podobieństwo” Syna Bożego:

„Odtąd Słowo Boże mocno go związało, jako zbiegłego niewolnika, i zawładnęło jego sprzętami (naczyniami), to znaczy ludźmi, którzy byli więzieni przez niego, a którymi on nieprawnie się posługiwał. Tak więc ten, który niesprawiedliwie uczynił człowieka niewolnikiem, sam słusznie został uczyniony niewolnikiem; a człowiek, który [wcześniej] został uczyniony niewolnikiem, został zabrany pod władzę swego właściciela, zgodnie z miłosierdziem, jakie Bóg Ojciec okazał swemu dziełu, udzielając mu daru zbawienia i przywracając go do stanu niezniszczalności przez Słowo, to znaczy przez Chrystusa, aby człowiek w oparciu o doświadczenie zrozumiał, że nie sobie samemu, ale Bożemu aktowi darowizny zawdzięcza niezniszczalność" ${ }^{33}$.

To Ojciec w swoim miłosierdziu podejmuje inicjatywę dzieła opisanej tu „reintegracji”, a dokonuje się ona przez działanie Chrystusa. Ireneusz prowadzi analogiczną przypowieść, opowiedzianą przez Jezusa w zdaniu z Mt 12, 29, aż do jej ostatecznego końca, który nie jest porażką „mocarza” (względnego), ani nawet zwycięstwem prawdziwego i absolutnego „Mocarza”, tylko „reintegracją” dóbr lub „naczyń”, to znaczy powrotem człowieka, który popadł pod władzę niesprawiedliwego użytkownika, do twórczej relacji ze

${ }^{30}$ Por. tamże III 18, 7, SCh 34, 324-326. Ten passus, szczególnie ważny dla chrystologii, zachował się w języku greckim w dziele Eranistes Teodoreta z Cyru, w dialogu II (Theodoretus, Eranistes II 169, ed. G.H. Ettlinger, Oxford 1975, 153).

${ }^{31}$ Irenaeus, Adversus haereses III 18, 7, SCh 34, 324-326.

${ }^{32}$ Tamże III 8, 2, SCh 34, 148.

${ }^{33}$ Tamże V 21, 3, SCh 153, 276-278. 
swoim prawowitym Panem ${ }^{34}$. Ta relacja pozwala przejść do realizacji podobieństwa, początkowo potencjalnego, z Synem Bożym i daje ciału niezniszczalność, to znaczy ożywienie Duchem, który jest „ożywczy”35.

\section{Trzech świadków Ireneuszowego dziedzictwa z IV wieku: Hilary} z Poitiers, Bazyli z Cezarei i Chromacjusz z Akwilei. Historia hermeneutyki i teologii tego wersetu jest dużo większa, niż pozwala o niej sądzić niemal całkowite milczenie współczesnych egzegetów ${ }^{36}$. Nie jest tu możliwe odtwarzanie szerzej tej historii, która ciągnie się przynajmniej aż do wczesnego średniowiecza, lecz chciałabym, na zakończenie, ukazać spuściznę Ireneusza, obecną jeszcze częściowo u kilku doktorów IV w., którzy zachowali preferencję niektórych z jej aspektów.

Hilary, na początku IV w., zachowuje z Ireneusza powiązanie między porażką szatana, który kusił Jezusa, i doprowadzeniem go do bezsilności. Zaczynając komentarz do Mt 12, 29 od łacińskiego tekstu ewangelicznego, zbliżonego thumaczeniem do tekstu łacińskiego Ireneusza, dodaje do wersetu uwagę (zgodną z tekstem Łukasza) - „i jest konieczne, aby czyniąc to, był on mocniejszy niż mocarz", i kontynuuje:

„Był on związany w momencie, w którym, nazwany «szatanem» przez Pana, poczuł się spętany przez samo nazwanie jego złośliwości; więc związawszy go, zabrał jego łupy i zawładnął jego domem, a tak nam, którzy niegdyś byliśmy jego zbroją i jego siłą zbrojną, umożliwił przejście pod swoją słuszną władzę" ${ }^{\text {37. }}$

Oto jak, à propos dwóch momentów zwycięstwa nad mocarzem u Ireneusza, A. Orbe precyzuje zestawienie czasu kuszenia i czasu męki: według Biskupa Lyonu ${ }^{38}$, „pierwsze [zwycięstwo], nad pokusami diabła, dokonuje się przez «zdemaskowanie» lub «obnażenie» nieprzyjaciela, zdrajcy i apostaty wobec Boga; pokornie akceptowane i przestrzegane przez Chrystusa jako

${ }^{34}$ Komentarz A. Orbe (Introduccion, s. 809) dociera tu do sedna intencji Ireneusza i rozszerza jej przesłanki dramatyczne: „Człowiek, gdziekolwiek by był, woła wielkim krzykiem do Boga, swego naturalnego Mistrza. I nawet jeśli mocarz niesprawiedliwie zawładnął nim i opanowuje go, on nie przestaje wołać do Stwórcy ze wszystkich swych sił". Por. A. Bastit-Kalinowska, L'Introduction d'Antonio Orbe à la théologie des II et III siècles et l'apologue du "Fort ligoté» (Mt 12, 29 et parallèles), „Gregorianum” 94 (2013) 286-300.

${ }_{35}$ Justyn (Dialogus cum Tryphone 39, PG 6, 559C-D), poprzednik Ireneusza, kładzie nacisk na fakt, że „dary” dane ludziom przez Chrystusa, gdy był On podwyższony, były darami Ducha.

${ }^{36}$ Por. uwagę F. Bovon (L'évangile selon saint Luc, s. 153): „Czytelnicy współcześni stawiają sobie pytania przy tym enigmatycznym tekście. Gotowi cieszyć się wyzwoleńczą władzą Jezusa, pozostają jednak zakłopotani wobec obrazowych zdań, jakie Galilejczyk przeciwstawia zarzutom i pokusom (ze strony) swoich przeciwników".

${ }^{37}$ Hilarius Pictaviensis, Commentarius in Matthaeum 12, 16, ed. J. Doignon, SCh 254, Paris 1978, 282. Co ciekawe, zauważmy, że w komentarzu do Mateusza Hilary komentuje tekst Łukasza.

${ }^{38}$ Por. Irenaeus, Adversus haereses V 21, 2, SCh 153, 270-272. 
człowieka wyrocznie Boga (lub Prawa), przykazania Stwórcy, demaskują nieprzyjaciela, zdrajcę i apostatę" ${ }^{39}$. Ale ,triumf krzyża koronuje zwycięstwo nad pokusami na pustyni. Ten, którego Chrystus, jako człowiek, zdemaskował na pustyni, został definitywnie pozbawiony swojej siły przez tego samego Chrystusa, Słowo, Syna Bożego, który umarł na krzyżu"40.

Bazyli, w 2. poł. IV w., dotyka ważnej kwestii, obecnej już w teologii Ireneusza: stosuje on wymiar symetryczny akcji z Mt 12, 29, z zastosowaniem przymusu, potem z zastosowaniem w pełni wolnej woli, skłonnej odtąd do dobrych dzieł. Jego punkt wyjścia jest całkiem inny niż u Hilarego: oddaje się on analizie różnych znaczeń przyimka „przez” ( $\delta$ ió), przy okazji której napotyka na werset z Listu do Rzymian - „we wszystkim tym jesteśmy bardziej zwycięzcami «przez» tego, który nas ukochał" (Rz 8, 37):

„W tym wyrażeniu, Apostoł nie sugeruje pokornej służby, lecz skuteczną pomoc dla żywotności mocy: sam [Jezus] związawszy mocarza, zawładnął jego naczyniami, to znaczy nami [...]; on nas wprowadził w stan, w którym możemy spełnić każde dobre dzieło, gdyż to, co zależy od nas, jest całkiem gotowe. Tak więc, przez Niego mamy przystęp do Boga, gdyż opuściliśmy władzę ciemności, aby «mieć udział w dziale świętych w światłości» (Kol 1, 12). Nie patrzmy więc na ekonomię dokonaną przez Syna jak na pomoc dostarczoną pod przymusem - narzuconą niewolnikowi ze względu na jego podległą kondycję - ale zobaczmy w Jego uprzedzającej trosce, którą On zdecydowanie otacza swoje dzieło, wyraz dobroci i miłosierdzia, który zgodny jest z wolą Boga Ojca"41.

W istocie „Słowo Boże” - pisał podobnie Ireneusz w Adversus haereses:

„odkupiło to, co było Jego własnością, nie «przez przemoc», na sposób której ona [apostazja] panowała nad nami na początku, chciwie zawładnąwszy tym, co nie było jej, ale «przez przekonywanie» (secundum suadelam), gdyż podobało się Bogu otrzymać «przez przekonywanie a nie przez przemoc» (suadentem et non vim inferentem) to, co chciał, aby sprawiedliwość została obroniona i aby dzieło niegdyś ukształtowane przez Boga nie zginęło"42.

Ireneusz i Bazyli kładą tu nacisk na delikatny aspekt uwolnienia człowieka, które jest podsumowane w zdaniu Mt 12, 29: zapewne niewola jest zniesiona dzięki miłosierdziu Bożemu i potędze odkupienia, ale człowiek w swojej aktywności życiowej pozostaje wolny; Syn Boży pragnie jego przylgnięcia, lecz nie narzuca mu go przemocą, jak można by myśleć na podstawie słów użytych w apologu.

${ }^{39}$ Orbe, Introduccion, s. 699. Orbe podkreśla wyrażenie „en cuanto hombre” - ,jako człowiek”.

${ }^{40}$ Tamże.

${ }^{41}$ Basilius Caesariensis, De Spiritu Sancto VIII 18, 100, ed. B. Pruche, SCh 17bis, Paris 1968, 308-310.

${ }^{42}$ Irenaeus, Adversus haereses V 1, 1, SCh 153, 19-21. 
U Chromacjusza, przy samym końcu IV lub w pierwszych latach V w., odnajdujemy zbiór motywów związanych z apologiem: rozróżnienie czasów; tyrańskie używanie przez diabła cudzej własności; przerwanie równowagi sił przez wcielenie Syna Bożego; status biernych ludzi, „utensyliów”; w końcu archaiczny związek z wizją wstępującą z Ef 4, 8 (obecną, jak widzieliśmy, u Melitona, Ireneusza i Orygenesa); a nawet bardzo Ireneuszową aluzję do „darów” udzielonych człowiekowi, którymi są niezniszczalność i zbawienie ciała przez potęgę wylanego Ducha:

„On pokazał, że tym «mocarzem» był Szatan, książę demonów, który w domu tego świata używał zniewolych ciał ludzi jak własnych naczyń. Istotnie zniewolił on całość rodzaju ludzkiego i metodą tyrańską panował nad wszystkimi, przez moc grzechu [...]. Aby związać tego mocarza, musiał przyjść «mocniejszy», jedyny Syn Boga, aby po związaniu mocarza, wyrwać nas z jego mocy, nas wszystkich, którzy byliśmy naczyniami (Mt, Mk) lub «łupami» (Łk) diabła; On jest rzeczywiście tym, który «wznosząc się na wysokość», jak to objawiają i Dawid i Apostoł (Ef 4, $8=$ Ps 67, 19), pociągnął za sobą uwięzioną niewolę i obdarował darami ludzi”"43.

Bardziej niż u Ireneusza, akcent jest położony na zbawienie ludzkich ciał przez ofiarę ciała Chrystusa i na kult człowieczeństwa Jezusa: począwszy od wersetu psalmu [,„błogosławiony niech będzie Pan, On moje ręce zaprawia do walki, moje palce do wojny" (Ps 143, 1)], Chromacjusz prowadzi rozmyślanie nad apologiem o mocarzu, aż do szczytu patetycznego współczucia:

„O wzięcie jakiej broni na ratunek rodzaju ludzkiego i na zniszczenie jego prześladowców, prosi prorok Pana, jeśli nie o to, żeby przyjął ludzkie ciało, przez które okazał człowiekowi ratunek swoim boskim miłosierdziem i zwycięsko odparł jego nieprzyjaciela, diabła, prześladowcę rodzaju ludzkiego? [...] Faktycznie, pokazuje On swoje ręce zaprawione do walki, te które dla zbawienia rodzaju ludzkiego przeciwdziałając diabłu, wzniósł na krzyżu, i swoje dłonie gotowe do wojny, te, które pozwolił przebić gwoźdźmi, aby móc zatriumfować nad diabłem"44.

Jest zrozumiałe, że werset o związanym mocarzu odegrał tak decydującą rolę w pierwszych wiekach. $Z$ tonem triumfalnym, wręcz heroicznym, sprzęga on dwa atuty: 1. wymiar ekonomiczny, bardzo tu obecny; 2. niemal maksymalną siłę koncentracji; ponieważ trudno jest wyobrazić sobie bardziej zwięzłe przypomnienie skutecznego czynu zbawczego względem człowieka.

\footnotetext{
${ }^{43}$ Chromatius Aquileiensis, Tractatus in evangelium Matthaei 50, 1, CCL 9A, 445.

${ }^{44}$ Tamże 50, 1, CCL 9A, 446.
} 
Zdanie to, jak widzieliśmy, ma charakter wspólny z najbardziej archaicznymi przedstawieniami „walki z mocami” u Pawła, szczególnie w dwóch najważniejszych miejscach: zwycięstwo apokaliptyczne nad „ostatecznym nieprzyjacielem" w 1 Kor 15, 26 i wspaniałe przywołanie triumfalnego wniebowstąpienia Zbawiciela (Ef 4, 8), który pociąga za sobą łupy wyrwane $\mathrm{z}$ „niewoli” ${ }^{45}$. Ponadto, pierwotna myśl chrześcijańska zstąpienie do posiadłości „mocarza” i starcie, które ma tam miejsce, sytuowała chętnie w piekle, w momencie descensus ad inferos.

U Ireneusza natomiast i u niektórych z jego czytelników, refleksja kieruje się w inną stronę, jak to pokazuje A. Orbe: „Można sobie wyobrazić miejsce zniewolenia człowieka przez «mocarza», w którym wszyscy, Adam i jego dzieci, są zgromadzeni i ściśle nadzorowani przez nieprzyjaciela. Odkupienie polegałoby na wyrwaniu nieprzyjacielowi więzionych przez niego ludzi. Perspektywa Ireneusza jest całkiem inna. Nieprzyjaciel nakłonił Adama do przekroczenia prawa. To wystarczyło, aby człowiek został więźniem grzechu i śmierci. Tylko ta niewola się liczy. Władza (lub „łańcuchy”) nieprzyjaciela mieszka dokładnie w przekroczeniu prawa (i w śmierci). Odkupienie polegałoby więc na wyrwaniu człowieka $\mathrm{z}$ władzy przekraczania prawa (i ze śmierci). Ipso facto człowiek będzie uwolniony z rąk mocarza, ponieważ posłuszeństwo Chrystusa względem Ojca zniszczyło na zawsze nieposłuszeństwo, które go więziło" ${ }^{4}$.

Widzieliśmy także, że mikro-opowiadanie z Mt 12, 29 służyło jako okazja pogłębienia teologicznego, którego głównym motywem nie jest już triumf Zbawiciela nad Złym (oczywiście proklamowany), ale natura istot zaangażowanych w ten dramat. Są to oczywiście ludzie stworzeni na początku na wzór Syna Bożego, skrępowani w używaniu wolnej woli przez konsekwencje grzechu, ale wykupieni od wszelkiego ucisku przez czynność zbawczą w taki sposób, aby mogli dobrowolnie oddać się swemu Stwórcy i otrzymać od niego dary, którymi są Duch i życie. $Z$ drugiej strony jest to Bóg w swej wspaniałomyślności trynitarnej: Bóg Ojciec, bogaty w miłosierdzie, który ma inicjatywę zbawienia, „Syn człowieczy” - Odkupiciel, przez którego posłuszeństwo dokonuje się zbawienie, Dar Ducha (czyli życie i niezniszczalność), który je udoskonala, bo Duch jest także Dominus et vivificans.

Poza tą medytacją nad zaangażowaniem trzech Osób Boskich w odkupieniu człowieka, pogłębione badanie Ireneusza kieruje się do źródła odpowiedniości wcielenia i zjednoczenia w Jezusie Syna człowieczego „tej samej natury, co jego ojcowie" i Syna Bożego, również współistniejącego ze swym Ojcem (doktor - Azjata nie wątpi w to, nawet jeśli tego nie precy-

${ }^{45}$ Jeszcze w VIII w. (i bez wątpienia także później) Beda Czcigodny w swoim komentarzu do Łukasza, przekazując zapis tradycyjny Łk 11, 21-22, łączy z nim triumfalną perspektywę z Ef 4, 8, którą cytuje, por. Beda Venerabilis, In Lucae evangelium expositio IV, ed. D. Hurst, CCL 120, Turnhout 1960, 234.

${ }^{46}$ Orbe, Introduccion, s. 815. 
zuje). Widać więc do jakiego stopnia sentencja synoptyczna okazała się dla Ireneusza teologicznie płodna.

Jan Paweł II napisał w swojej książce-wywiadzie Pamięć i tożsamość, wydanej w 2005 r., że ,istnieje granica narzucona złu, która jest miłosierdziem Bożym" ${ }^{47}$. W ten sposób autor trylogii Redemptor hominis, Dives in misericordia oraz Dominum et vivificantem ${ }^{48}$ wyraził we współczesnych słowach to, co przypowieść o związanym „mocarzu” chciała powiedzieć pierwszym - a może i dalszym - pokoleniom chrześcijańskim.

\author{
„TO TIE THE STRONG MAN”- \\ THE BATTLE OF JESUS AND BEELZEBUB. \\ ANCIENT EXEGESIS OF MATTHEW 12, 29 AND PARALLEL TEXTS
}

\title{
(Summary)
}

Although Peter seems to echo the opinion commonly held when he says that Jesus „went about doing good” (Act 10, 38), Jesus was accused of „casting out demons by Beelzebub, the ruler of the demons" (Mt 12, 24). In answer, he proposes a very short parable, the one of the "Strong one" tied up to seize his goods (Mt 12, 29). The present article studies the influence of this verse in the early Christian literature. The victory of the Saviour over evil is interpreted as the result of a cosmic fight (Origen) or as the merciful redemption of the human being and his restoration and vivification by the Holy Spirit (Irenaeus).

Slowa kluczowe: mocarz, egzegeza, Mt 12, 29.

Key words: strong man, exegesis, Mt 12, 29.

${ }^{47}$ Jan Paweł II, Pamięć i tożsamość, Kraków 2005, 25nn.

${ }^{48} \mathrm{~W}$ pierwszej części tej książki w rozdz. II autor omawia trzy pierwsze swoje encykliki, datujące się odpowiednio na lata 1979, 1980 i 1986, jako trylogię będącą odpowiedzią na „filozofię zła”. 
